University of Nebraska - Lincoln

DigitalCommons@University of Nebraska - Lincoln

Entomology Papers from Other Sources

Entomology Collections, Miscellaneous

1998

\title{
Monitoring Solitary Bees in Modified Wildland Habitats: Implications for Bee Ecology and Conservation
}

\author{
Gordon Frankie \\ Division of Insect Biology, CNR University of California, Berkeley, CA 94720 \\ Robbin W. Thorp \\ Department of Entomology, University of California, Davis, CA 95616 \\ Linda E. Newstrom-Lloyd \\ Current address: Department of Plant and Microbial Sciences, University of Canterbury, Private Bag 4800 \\ Christchurch, New Zealand \\ Mark A. Rizzardi \\ Department Of Biostatistics, University Of California, Berkeley, CA 94720 \\ John F. Barthell \\ Division of Insect Biology, CNR University of California, Berkeley, CA 94720 \\ See next page for additional authors \\ Follow this and additional works at: https://digitalcommons.unl.edu/entomologyother \\ Part of the Entomology Commons
}

Frankie, Gordon; Thorp, Robbin W.; Newstrom-Lloyd, Linda E.; Rizzardi, Mark A.; Barthell, John F.; Griswold, Terry L.; Kim, Jong-Yoon; and Kappagoda, Shanthi, "Monitoring Solitary Bees in Modified Wildland Habitats: Implications for Bee Ecology and Conservation" (1998). Entomology Papers from Other Sources. 108.

https://digitalcommons.unl.edu/entomologyother/108

This Article is brought to you for free and open access by the Entomology Collections, Miscellaneous at DigitalCommons@University of Nebraska - Lincoln. It has been accepted for inclusion in Entomology Papers from Other Sources by an authorized administrator of DigitalCommons@University of Nebraska - Lincoln. 


\section{Authors}

Gordon Frankie, Robbin W. Thorp, Linda E. Newstrom-Lloyd, Mark A. Rizzardi, John F. Barthell, Terry L. Griswold, Jong-Yoon Kim, and Shanthi Kappagoda 


\title{
Monitoring Solitary Bees in Modified Wildland Habitats: Implications for Bee Ecology and Conservation
}

\author{
GORDON W. FRANKIE, ${ }^{1}$ ROBBIN W. THORP ${ }^{2}$ LINDA E. NEWSTROM-LLOYD, ${ }^{3}$ \\ MARK A. RIZZARDI, ${ }^{4,5}$ JOHN F. BARTHELL, ${ }^{1,2,6}$ TERRY L. GRISWOLD, ${ }^{7}$ JONG-YOON KIM, ${ }^{2}$ AND \\ SHANTHI KAPPAGODA ${ }^{1}$
}

\begin{abstract}
Environ. Entomol. 27(5): 1137-1148 (1998)
ABSTRACT The long-term goal of this study was to use solitary bees to assess the impact of advancing Africanized honey bees (Apis mellifera scutellata Lepeletier) on the native California bee fauna. Cavity-nesting, solitary bee species were systematically monitored in wooden trap nests at 6 sites in northern central California from 1990 to 1992. Three sites were in the San Joaquin Valley in wildlife refuges or preserves; 3 were in coastal mountain or Sierran foothill parks or reserves. Differences in frequencies of nesting bees were observed and recorded among sites and habitats through time. A Poisson regression indicated that all explanatory variables and their lst order interactions were highly significant. There were significant differences among bee taxa, sites and years, and their interactions (bee $\times$ site; bee $\times$ year; site $\times$ year). Megachile species were the predominant cavity nesters in the 3 valley sites; Osmia species were the common group in coastal mountain/ foothill sites. In a computer simulation, using a variation of the Poisson regression, several significant differences were also observed between yearly frequency counts for certain bee species at the same site. Possible reasons for year to year changes included differential natural mortality, extreme annual weather patterns, use of marginal habitats, and negative impacts from exotic solitary bee species. Three exotic megachilids (Megachile rotundata (F.), M. apicalis Spinola, and M. concinna Smith) have successfully invaded and become established in California. Possibly, M. apicalis has affected other cavity nesting bee species, including the exotic M. rotundata in our Central Valley sites.
\end{abstract}

KEY WORDS Megachile, Osmia, Megachilidae, trap nests, bee conservation, bee monitoring

WOODEN TRAP NESTS HAVE been used for years by biologists to lure bees and wasps to make their nests, where they can be easily studied (Krombein 1967). Some of the studies were designed for simple surveys of species present (Parker and Bohart 1966, 1968; Torchio1984; Frohlich and Parker 1985; Parker 1986, 1987; Jacob-Remacle 1986; Beyer et al. 1987), whereas others provided information on preferred habitats (Medler and Koerber 1958, Jayasingh and Freeman 1980, Frankie et al. 1988, Gathmann et al. 1994) or experimental use in nest recognition (Tepedino et al. 1979, Raw 1992). More recently, trap nests have been used to monitor selected species through time in several sites to record possible frequency changes and

\footnotetext{
${ }^{1}$ Division of Insect Biology, CNR University of California, Berkelev, CA 94720.

${ }^{2}$ Department of Entomology, University of California, Davis, CA 95616.

${ }^{3}$ Current address: Department of Plant and Microbial Sciences, University of Canterbury, Private Bag 4800 Christchurch, New Zealand.

${ }^{4}$ Department of Biostatistics, University of California, Berkeley, CA 94720 .

${ }^{5}$ Current address: Department of Mathematics, Humboldt State University, Arcata, CA 95521.

${ }^{6}$ Current address: Department of Biology, University of Central Oklahoma, Edmond, OK 73034.

${ }^{7}$ Bee Biology \& Systematics Laboratory, USDA-ARS, Utah State University, Logan, UT 84322.
}

constancy to habitat type (Frankie et al. 1993, Strickler et al. 1996).

The field study reported here was initiated in 1987 in northern California to gather baseline ecological information on solitary bees and European honey bees (Apis mellifera L.) before arrival of the Africanized honey bee (Apis mellifera scutellata Lepeletier) in the northern part of the state. Once the Africanized honey bees arrived, this information would serve as a basis for evaluating differences in impact of Africanized honey bees versus European honey bees on solitary bees (Thorp et al.1992).

We used 2 approaches to gather the ecological data. The 1st was to select 6 study sites in northern California and then intensively survey European honey bees and solitary bees from flowers throughout the year at each site during a period of several years (1987-present). This was done to gain an understanding of the full range of species present, their general levels of abundance and seasonality at preferred flowers, degree of overlap with European honey bees at shared flowers, and their general nesting habits where possible. Results of this study, which are extensive, will be reported elsewhere.

The 2nd approach focused on selected cavity-nesting bee species that could be monitored with wooden trap nests during a period of several years (Thorp et al. 1992). The goal was to develop quantitative infor- 


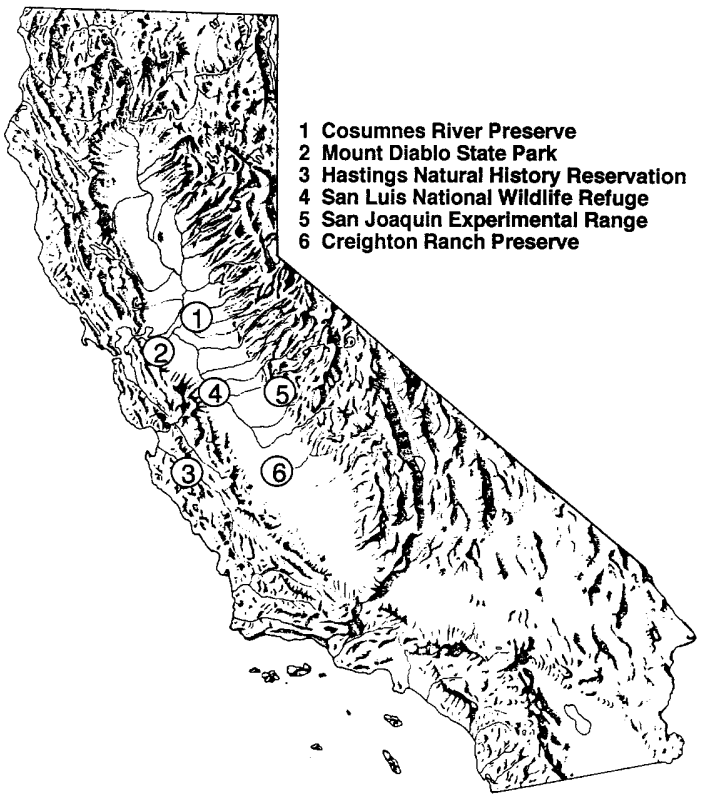

Fig. 1. Six study sites in northern California for long-term monitoring of bee communities.

mation on frequencies of bee species, their seasonal phenologies, and possible changes in frequency from year to year. The study reported herein provides information on these frequencies over a 3 -yr period (1990-1992) on several bee species that use preexisting tree-hole cavities for nesting. Seasonal phenologies and details on nesting biology will be reported in later articles. The specific questions addressed in this paper are the following: Which solitary bee species use preexisting cavities to make their nests, and are there significant differences in bee species composition among sites? What are the frequencies of selected solitary bee species by site and by year, and do they change significantly through time? Is there evidence that exotic solitary bee species are competing with California native solitary bee species for nesting cavities?

Study Sites. Six study sites were chosen in central California to inventory and monitor trap-nesting solitary bees. Sites were selected with the expectation that they would eventually be occupied by the invading Africanized honey bees, whereupon they would be useful for making before and after comparisons. Some information was already available on the diversity of the native bee fauna at several sites from past studies or collections of the University of California (Berkeley and Davis). All sites were located within managed or protected areas.

Three sites were selected in the San Joaquin Valley in wildlife refuges or preserves. These were (from N to S) Cosumnes River Preserve (site 1), San Luis National Wildlife Refuge (site 4), and Creighton Ranch Preserve (site 6) (Fig. 1). The coastal mountain sites were Mount Diablo State Park, Contra Costa County (site 2), Hastings Reserve in Carmel Valley,
Monterey County (site 3); and the 3rd site was in the San Joaquin Experimental Range in the southern Sierra Nevada foothills (site 5) (Fig. 1).

Cosumnes River Preserve (CO). The 2,104-ha preserve is owned by The Nature Conservancy and managed jointly with the California Department of Fish and Game, the U.S. Bureau of Land Management, Ducks Unlimited, the Wildlife Conservation Board, the American Farmland Trust, and Sacramento County Department of Parks and Recreation (it was only 1,377 ha when we started). It is located in southern Sacramento County, $\approx 16 \mathrm{~km}$ west of Galt. It lies in the floodplain of the Cosumnes River near the confluence with the Mokelumne River. There are 3 primary plant communities: (1) riparian forest with valley oak (Quercus lobata Nee), Fremont cottonwood (Populus fremontii S. Watson), buttonbush (Cephalanthus occidentalis variety californicus Benth), Oregon ash (Fraxinus latifolia Benth), box elder [Acer negundo (Torrey \& A. Gray) Sarg] and 4 species of willow (Salix spp.) (the valley oaks are reproducing because of annual flooding which protects acorns and seedlings from vertebrate herbivory); (2) freshwater marsh with tules (Scirpus) and cattails (Typha); (3) annual grasslands and cultivated fields occupy the drier parts of the Preserve. There are active programs to replant valley oaks and to reconstruct marsh habitat for waterfowl, especially in the grassland habitats. The elevation is $<30 \mathrm{~m}$ above sea level, and average annual rainfall is $410.7 \mathrm{~mm}$ (based on $30+\mathrm{yr}$ at nearby town of Lodi).

San Luis Wildlife Refuge (SL). The refuge, which lies within the historic flood plain of the San Joaquin River, consists of 6,205 ha (it was 2,973 ha when we started) of a mixture of grasslands (54\%), wetlands $(37 \%)$, and riparian habitat $(9 \%)$. It is managed by the U.S. Fish and Wildlife Service. Most of the wetlands are seasonal marshes that are subject to carefully controlled flooding, which begins in late September and October. The most common tree found along riparian corridors is willow (2 Salix spp.). Other less common trees and shrubs include Populus fremonti, and rarely Quercus lobata, Sambucus mexicana C. Presl, and Cephalanthus occidentalis variety californicus. Elevation ranges from 23 to $27 \mathrm{~m}$, and average annual rainfall is $218.4 \mathrm{~mm}$ (based on $30+\mathrm{yr}$ at nearby city of Los Banos).

Creighton Ranch (CR). The 1,338-ha preserve is owned by J. G. Boswell and until recently (May 1995) was managed by The Nature Conservancy. It is located at the margin of the historic Tulare Lake Basin and is divided by 1 of its tributaries, the Tule River. The area contains a mixture of grasslands and seasonal wetlands, which are bound by levees. Along the Tule River bed the following trees and shrubs are common: Salix spp., Cephalanthus occidentalis variety californicus, Populus fremonti, Prosopis glandulosa variety torreyana (L. Benson) M. Johnston, and Quercus lobata. The site is subject to seasonal flooding, and water is sometimes stored temporarily within some embankments. Water is also withheld from the site during other years. The elevation is $\approx 18 \mathrm{~m}$, and average 
annual rainfall is $176.8 \mathrm{~mm}$ (based on $30+$ yr at nearby city of Corcoran).

Mount Diablo State Park (MD). The 2,856-ha Park is owned and operated by California State Parks. It is in the central inner coast range $\approx 13 \mathrm{~km}$ southeast of Walnut Creek in Contra Costa County. The primary plant communities are central California oak-conifer, chaparral, and grassland. We selected 3 monitoring subsites in the southwest corner of the Park between 305 and $610 \mathrm{~m}$ elevation. These sites are primarily in oak or oak-conifer communities adjacent to grasslands. One site was adjacent to an area grazed by cattle. Range of elevation in the Park is from $\approx 183$ to $1,173 \mathrm{~m}$, and average annual rainfall is $404.6 \mathrm{~mm}$ (based on $30+\mathrm{yr}$ at nearby city of Walnut Creek).

San Joaquin Experimental Range (SJ). The 1,790-ha range is jointly owned and operated by U.S. Forest Service and CSU Fresno. It is $\approx 37 \mathrm{~km}$ NE Madera in the southern Sierra foothills of Madera County (also $\approx 45 \mathrm{~km} \mathrm{~N}$ Fresno). The plant communities consist of oak woodland with gray pine and Ceanothus, poison oak (Toxicodendron), and manzanita (Arctostaphylos); and grasslands. Approximately $90 \%$ of the cover is annual plants including $>400$ species, most of which are introduced. Cattle grazing occurs over most of the range, except for a 33-ha block designated as a Research Natural Area by the Forest Service. Our 3 monitoring subsites were mostly savanna (oak-grassland) habitats including 1 in the ungrazed Research Natural Area. Most of the Range has residual soils from decomposition of underlying granite. There are also large granite outcroppings that contain many bee plants. The elevation ranges from 213 to $518 \mathrm{~m}$, and average annual rainfall is $348.7 \mathrm{~mm}$ (based on $30+\mathrm{yr}$ at nearby Friant Government Camp).

Hastings Reserve (HR). The reserve is composed of 911 ha in the foothills of the Santa Lucia Mountains, $42 \mathrm{~km}$ inland from the coast at the upper end of Carmel Valley. The 3 main vegetation types are mixed evergreen forest $(40 \%)$, oak woodland $(30 \%)$, and chaparral $(20 \%)$. The most common trees are Quercus lo$b a t a$, which dominates the open woodland, Quercus douglasii Hook. \& Arn., and Quercus agrifolia Nee. Other less common species include Quercus kelloggii Newb, Arbutus menziesii Pursh, and Toxicodendron diversilobum (Torrey \& A. Gray) E. Greene. There is limited riparian habitat along 3 intermittent streams. The elevation ranges from 467 to $953 \mathrm{~m}$, and average annual rainfall is $527.1 \mathrm{~mm}$ (based on $30+$ yr at Hastings Reserve).

From 1987 to 1992 , northern California experienced generally severe drought conditions. Below average rainfall was recorded annually in all sites, with exceptions in some localities for 1992 (e.g., San Luis) (source: local $30+\mathrm{yr}$ weather records). The drought broke during the winter of 1994-1995 when record levels of precipitation were recorded.

Human disturbance was most notable at the 3 valley sites, which are being actively managed for migratory waterfowl or irrigation. At Cosumnes, restoration of Quercus lobata is being conducted on a large scale. In addition to restoration plantings of oaks, considerable areas of marsh and ponds have been developed for waterfowl in cooperation with Ducks Unlimited. Extensive restoration of marshes and selected riparian corridors is also in progress at San Luis; the latter with 4 native tree species and 3 native shrub species. At Creighton Ranch, water is routinely stored or withheld from the site for agricultural use. Withholding is especially noticeable during drought years. The native habitats of Mount Diablo and Hastings Reserve are both largely intact. The former is managed for limited recreation and conservation of biodiversity; whereas the latter is managed primarily for field research through the University of California Natural Reserve system. The San Joaquin site is an experimental range where a considerable amount of grazing has been one of the long-term objectives.

\section{Materials and Methods}

First Phase of Study: 1987-1989. During this period a wealth of background information was collected on the study sites, their tree cavity and ground-nesting bee species, their floral resources, general bee phenology, biotic mortality factors, and on field sampling procedures. At the end of 1989, this information was used to design a long-term bee monitoring study of solitary bees at 6 northern California sites (Thorp et al. 1992).

The 1st yr (1987) was spent exploring and selecting available protected areas in northern and central California that would be suitable for solitary bee studies. Cavity nesting bees were sampled periodically at each site by using wooden trap nests originally designed for a Costa Rican study (Frankie at al. 1988, 1993). Rate of filling trap nest blocks with nesting bees was carefully monitored during the preliminary phase to ensure that a given set of blocks at a site would never become fully saturated with bees and thereby confound the frequencies generated from the sampling procedure. The focus was on tree cavity nesters because quantitative sampling procedures could be developed for this ecologically related group of bees, whereas sampling for ground nesters at nest sites proved to be impractical.

During the 2nd and 3rd yr, refinements in field data collections were made. Methods were developed to systematically collect data on bees in trap nest blocks and to rear them under laboratory conditions at the UC Berkeley and UC Davis campuses. Bees were sent to the USDA bee laboratory at Utah State University, Logan, where they were identified by one of us (T.L.G.). At the end of the 3rd yr, the trap nest design was modified to accommodate specific types and size classes used by solitary bees found in California (Thorp et al. 1992). One study site on the south side of Mt. Diablo State Park was eliminated in 1989 because of a drought-induced lack of bees collected there. A replacement trapping site was located at Mt. Diablo and sampling was started again in 1991.

Second Phase of Study 1990-1992. Cavity-nesting bees were monitored systematically at each of the 6 sites through the use of a block-sampling unit con- 
taining 12 sticks (stick sampling unit) with drilled holes. Based on preliminary data gathered during 1987-1989, the block-sampling unit was standardized as well as the number of block-sampling units per site, sampling frequency, and season of placement, starting in 1990. The block-sampling units used in the 2nd phase (1990-1992) consisted of a block of 12 straightgrained pine sticks (stick sampling units): each measuring 19 by 23 by $117 \mathrm{~mm}$, with a centered hole drilled lengthwise to a depth of $10 \mathrm{~cm}$. The sticks were divided equally into 3 hole sizes: $4.7 \mathrm{~mm}\left(3 / 16^{\prime \prime}\right), 6.3 \mathrm{~mm}$ $\left(1 / 4^{\prime \prime}\right)$, and $7.8 \mathrm{~mm}\left(5 / 16^{\prime \prime}\right)$ in diameter. They were arranged in a standard design within the block (Thorp et al. 1992).

Nine block-sampling units were placed at each site and replaced every $3 \mathrm{wk}$ during the nesting season. Blocks were scattered widely in representative subsites within a site by hanging them on a nail $\approx 1.5-2 \mathrm{~m}$ above ground; on mostly vertically shaded or partially shaded trunks or major branches of live trees. If blocks became too exposed to the sun, through leaf and branch falls, they were moved to nearby shady locations. Shaded locations chosen as earlier studies ( $\mathrm{Ar}$ retz 1969, 1973; Undurraga and Stephen 1980) had shown that larval mortality of selected Megachile species was significantly higher in exposed versus shaded ones (see also Barthell et al. 1998, Frankie et al. 1988). Blocks were also moved when ants occasionally colonized them. The same subsites were used throughout the entire study. Based on our preliminary studies, block-sampling units were monitored at the coastal mountain/foothill sites from late February to May/ June and at the valley sites from May/June to early October. One set of blocks was left out from June into October at the 3 coastal mountain/foothill sites to ensure that possible summer cavity nesters were not missed. Field-collected blocks were put into an ice chest and transported to UC Berkeley or UC Davis where they were processed for rearing. Stick-sampling units that had an apparent bee occupant (or possible wasp) were recorded and separated out for rearing. Rearing was managed by fixing a small glass vial over the stick opening and attaching it with masking tape or placing the stick-sampling units into small plastic containers. Both housings served to catch earlyemerging parasites and predators or early-emerging bees. The stick-sampling rearing units were mostly kept at room temperature.

Voucher collections of reared insect material were mounted and sent to specialists for identification. Voucher specimens of all bees are maintained in the R.M. Bohart Museum of Entomology on the UC Davis campus and in the Essig Museum on the UC Berkeley campus.

Frequencies and histograms were generated from the compiled data. Poisson regression analysis was then used to analyze patterns of selected bee species for which there was sufficient data. The goal of these analyses was to determine if there were significant differences among the bees as to site and changes in frequency from year to year. Supersedures, where one species constructed its nests on top of another, were also recorded, but their outcomes (i.e., emergence successes and failures) were not studied in a controlled manner because their frequencies were relatively low. These data were subsequently removed from statistical analyses.

To analyze the differences in frequency of nesting bees in stick-sampling units among sites and habitats, the generalized linear model (GLM) with the log link was used on the statistical package S-plus (Version 3.1) (Payne 1986). The importance of the model's explanatory variables was assessed by using Poisson regression and comparing the difference in deviance (a goodness-of-fit measure) between the model with and without the explanatory variable of interest. The significance of change in deviance was evaluated by the chi-square distribution with the appropriate degrees of freedom (see McCullagh and Nelder 1989 for comprehensive reference).

Poisson regression was used because the study produced count data. Search and selection of a hole for nesting by each bee within a suitable habitat was assumed to be an independent and random process, which suggested that the Poisson distribution was a plausible description of the counts. Further, the estimated parameters were each highly statistically significant from 0 ( $P$ value $<0.001)$ such that even with the estimated dispersion parameter of 1.29 (ideal is 1.00) the statistical significance of the parameters would hold. Poisson regression was also used to analyze a similar data set on nesting bees in Costa Rica (Frankie et al. 1993).

Interest as to which bee species counts changed between years at the same site led to a simulation test, which focused on the question of whether annual differences were attributable to chance alone. Assuming that annual bee counts were distributed according to a Poisson distribution with a mean equal to the average of the 3 yearly counts, 1,000 simulated vectors of 3-yr nest counts were created. Using a Poisson regression model consisting of only an intercept, the deviance was calculated for each simulated 3-yr count and for the actual 3-yr nest count. Deviance of the actual data were ranked with the other deviances to assess how much the actual 3-yr nest count did not agree with the assumption of the $3 \mathrm{yr}$ being described by the same Poisson distribution. Because of only 2 -df difference between the saturated and null model, 1,000 simulations, rather than the chi-squared distribution, were used to assess significance of the year as an explanatory variable to describe the bee count for a particular species at a particular site.

\section{Results}

All bee and wasp species and other arthropod taxa that used trap-nest sticks during the 3-yr monitoring period (1990-1992) are listed in Table 1. Bees belonging to the family Megachilidae were the predominant group found in the sticks. The 2 most frequent bee genera were Megachile and Osmia. Sphecid wasps of the genus Trypoxylon were also commonly encountered. To a much lesser extent, other organisms such 
Table 1. Bee and wasp species and other taxa known to nest in trap nest blocks in 6 California sites

\begin{tabular}{|c|c|}
\hline Code & Bee $\operatorname{taxa}^{a}$ \\
\hline & Megachilidae \\
\hline AMC & Anthidium maculosum Cresson \\
\hline ASP & Ashmeadiella ${ }^{b}$ spp. \\
\hline MAN & Megachile angelarum Cockerell \\
\hline MAP & Megachile apicalis ${ }^{c}$ Spinola \\
\hline $\mathrm{MCN}$ & Megachile concinna $a^{b, c}$ Smith \\
\hline MET & $\begin{array}{l}\text { Megachile, SUBGENUS Eutricharaea (rotundata, } \\
\text { apicalis, concinna) }\end{array}$ \\
\hline MFD & Megachile fidelis Cresson \\
\hline MGN & Megachile gentilis ${ }^{b}$ Cresson \\
\hline MLT & Megachile SUBGENUS Litomegachile (gentilis) \\
\hline MRT & Megachile rotundata ${ }^{c}(\mathrm{~F})$. \\
\hline MSY & Megachile, SUBGENUS Sayapis (fidelis) \\
\hline MSP & Megachile spp. \\
\hline OBK & Osmia bakeri ${ }^{b}$ Sandhouse \\
\hline OCA & Osmia californica ${ }^{b}$ Cresson \\
\hline $\mathrm{OCO}$ & Osmia coloradensis ${ }^{b}$ Cresson \\
\hline OGL & Osmia glauca ${ }^{b}$ (Fowler) \\
\hline OLT & Osmia latisulcata ${ }^{b}$ Michener \\
\hline OLG & Osmia lignaria Say \\
\hline ORB & Osmia ribifloris Cockerell \\
\hline OTX & Osmia texana Cresson \\
\hline OSP & Osmia spp. \\
\hline PRB & Protosmia rubifloris (Cockerell) \\
\hline \multirow[t]{3}{*}{ BUN } & Bee species undetermined \\
\hline & Wasp taxa \\
\hline & Specidae \\
\hline ISO & Isodontia ${ }^{b, d}$ sp. \\
\hline TRY & Trypoxylon ${ }^{d} \mathrm{spp}$. \\
\hline SOL & Solierella ${ }^{b, d} \mathrm{sp}$ \\
\hline AUP & Auplopus ${ }^{e}$ sp. \\
\hline EUM & Eumenidae \\
\hline VES & Vespula ${ }^{b f}$ \\
\hline \multirow[t]{4}{*}{ WUN } & Wasp undetermined \\
\hline & Other taxa \\
\hline & Earwig, unident. hemipteran, ${ }^{b}$ unident. \\
\hline & lepidopteran, sowbug, ${ }^{b}$ spider, ant ${ }^{b}$ \\
\hline
\end{tabular}

See Thorp et al. (1992) for distribution of species among the sites. ${ }^{a}$ All bees are in the Megachilidae.

${ }^{b}$ Very rare; encountered $<12$ times overall for all sites, over $3 \mathrm{yr}$. ${ }^{c}$ Exotic to California.

${ }^{d}$ Sphecidae.

${ }^{e}$ Pompilidae.

${ }^{f}$ Vespidae.

as earwigs, spiders, and crickets were found using the holes for shelter or nesting.

The preliminary study phase (1987-1989) and main study (1990-1992) indicated that cavity-nesting bees in coastal mountain/foothill and valley sites varied greatly in their seasonal nesting periods. Species of coastal mountain/foothills, which were different, nested mostly during spring months, whereas valley species nested primarily during summer and early fall months. Time of the former was relatively brief from March through May; that of the valley was longer, from May through mid-October (Thorp et al. 1992). In general, Megachile species were the predominant cavity nesters in the valley sites; whereas, Osmia species were the common group in the coastal mountain/ foothill sites (Figs. 2-4; Thorp et al. 1992).

Bee nesting occasionally exceeded availability of holes in some blocks at some subsites at San Luis and Cosumnes during 1990-1992. For example, at San Luis, nesting by Megachile apicalis Spinola was high during the peak period (late August and September), and several blocks occasionally had all their holes filled with capped bee nests. Filling of blocks also occurred during the same period at Cosumnes, but at a lower frequency (Fig. 3). Despite this intensive nesting activity, there were always some blocks out of 9 at any given site that had some available holes. Thus, the sampling procedure was considered adequate to meet the objectives of the study. Further, because there were always high populations of the same bee species at most sites during the nesting season (see below for exception), as indicated by our trapping and bee collections at the same flower species, we assumed that the small numbers of blocks per site did not affect or deplete resident bee populations.

Valley Sites. Indigenous bees and wasps and exotic bee species were greatest in diversity and frequency in 2 of the 3 valley sites as compared with coastal mountain/ foothill sites (Figs. 2-4). Overall, Cosumnes had the greatest diversity of bee species and highest representation within each species. San Luis had a slightly lower diversity of cavity-nesting bees, and representation of each species was considerably less. For example, 3 indigenous bee species, Megachile angelarum Cockerell, M. fidelis Cresson, and Osmia texana Cresson, which occurred occasionally to commonly each year in Cosumnes, were only rarely encountered in some years at San Luis (Fig. 2). The greater diversity and development of habitat types at Cosumnes, especially forested riparian areas, may be responsible for some of the higher representation of bee species found there. In contrast, the relatively few types of forested habitats at San Luis that are suitable for cavity nesters, seem to favor the exotic Megachile apicalis and especially the Trypoxylon wasps, which occurred in high numbers (Figs. 2 and 3).

The diversity and representation of bee species at Creighton Ranch was very low during the 3-yr study from 1990-1992. In 1987, however, when preliminary field studies were initiated, this was an active site for bee nesting. Most nesting bees in that year and in 1988 were Megachile (Eutricharaea) concinna Smith. In addition to M. concinna, several other species of megachilid bees were trapped and most were collected in 1988 . These were Ashmeadiella aridula astragali Michener, Megachile angelarum, Megachile occidentalis Fox, Dolichostelis laticincta Cresson, Megachile (Eutricharaea) apicalis, Megachile (Eutricharea) rotundata (F.), Megachile inimica jacumbensis Mitchell, and Stelis sp. By 1989, populations of cavity-nesting bees at Creighton had crashed; only a very few sticks had occupant bees. This pattern persisted through the remainder of the study. It appeared that drought conditions and irregular flooding regimes at the Ranch may have contributed substantially to the decline of the bees. The woody vegetation at Creighton, especially Quercus lobata, also showed corresponding signs of decline during this period. This may be related to a receding water table, which is well known for this region where the landscape has received heavy agricultural use over the years.

Coastal Mountain/Foothill Sites. Overall frequency of nesting bees in coastal mountain/foothill sites (Fig. 


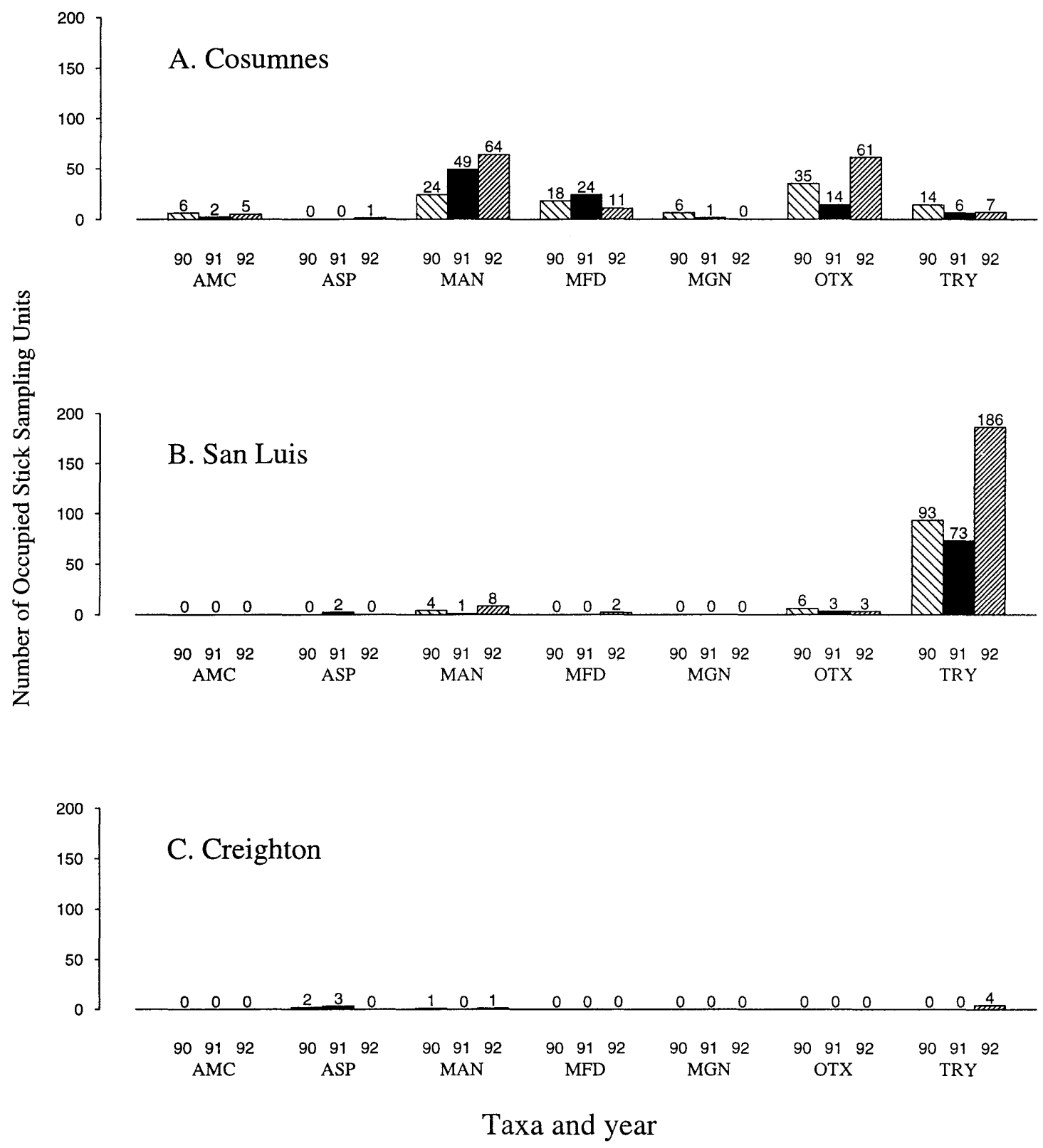

Fig. 2. Annual frequencies of indigenous bees and wasps monitored from 1990 to 1992 at trap nests from 3 central valley sites (A-C). See Table 1 for full names of taxa.

4) was noticeably lower than that observed in the valley sites with the exception of the Creighton Ranch. The San Joaquin site had higher bee species diversity as compared with Mount Diablo and Hastings; however, Osmia lignaria Say was the most frequently encountered bee at all 3 sites. Coastal mountain/foothill sites differed from valley sites in 2 important aspects: bee taxa between the 2 major types of sites were dramatically different; and, no exotic bee species were observed nesting in blocks at any of the coastal mountain/foothill sites. There were exceptions, however, with rare collections of Osmia texana at Hastings and Trypoxylon wasps at San Joaquin and Mount Diablo. Further, Megachile apicalis has been collected from flowers at all coastal mountain/foothill sites (J.F.B., unpublished data) but in numbers too low to be detected in trap nests.

Analyses of Frequency Data. Differences in frequencies of nesting bees were observed among sites and habitats through time (Figs. 2-4). To analyze these differences, the Poisson regression was used. Six bee species and 1 wasp taxon, for which there were 


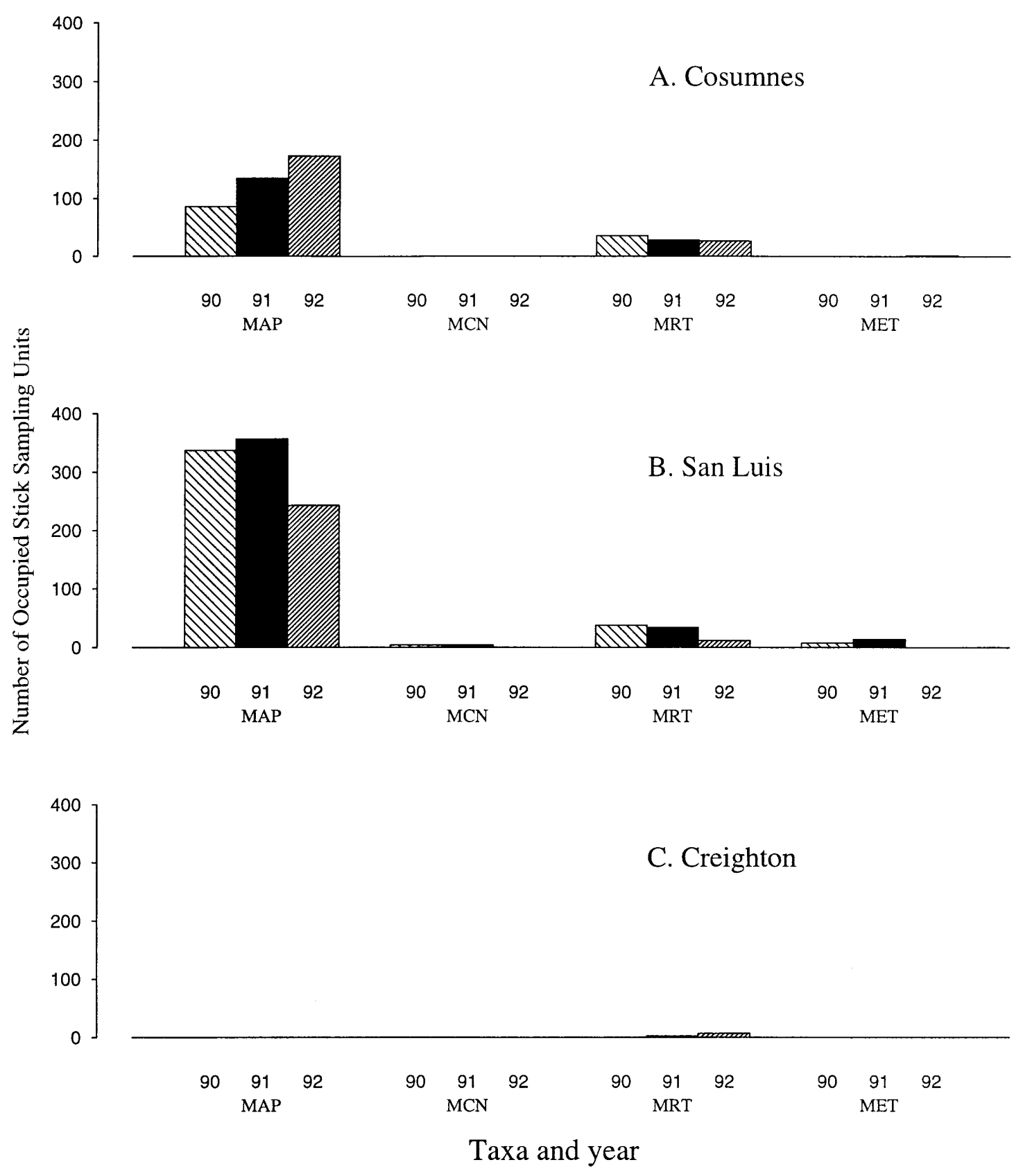

Fig. 3. Annual frequencies of exotic bee species monitored from 1990 to 1992 at trap nests from 3 central valley sites (A-C). See Table 1 for full names of taxa.

sufficient data, and 4 sites, for which there were 3 consecutive years of data, were used in this analysis. All explanatory variables and 1st order interactions were highly significant $(P<0.01)$ (Table 2$)$. The saturated model was not significant; nonetheless, the meaning of a bee $\times$ site $\times$ year interaction is not clear in a biological context. The 2-factor interaction, year $\times$ bee, for example, could be interpreted as indicating that different bee species are affected un- equally by weather differences of different years. Stated differently, yearly differences in nest counts were not uniform among different bee species. Likewise, site $\times$ bee significance suggests that habitat differences at the various sites favored one species over another; that is, the difference between different bee species counts at a site would not necessarily be the same at another site. Finally, the site $\times$ year interaction could be interpreted as site conditions (effects) 


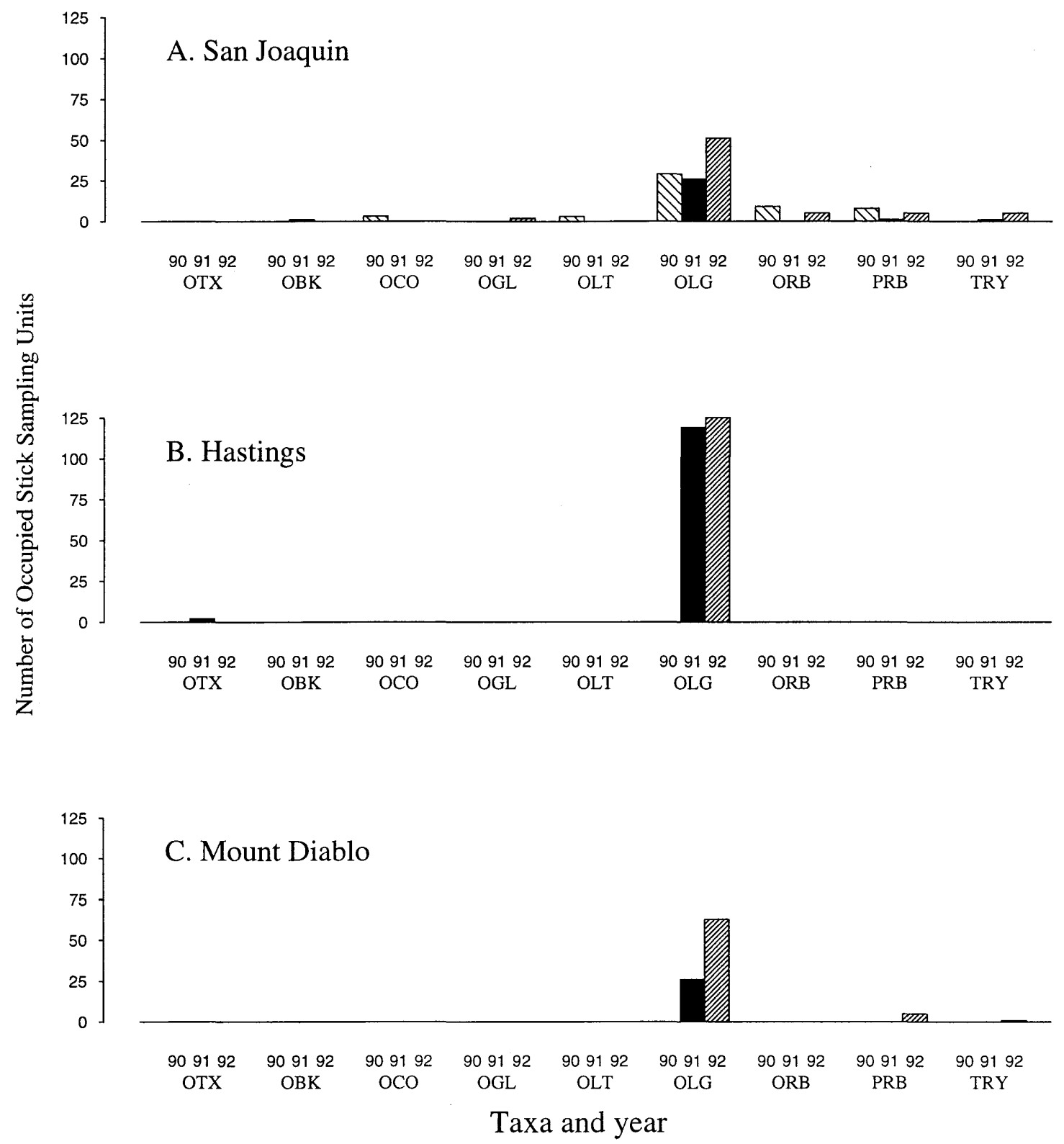

Fig. 4. Annual frequencies of indigenous bees and wasps monitored from 1990 to 1992 at trap nests from coastal mountain/foothill sites (A-C). See Table 1 for full names of taxa.

change through the years, but the change is not necessarily uniform across all sites.

Supersedures were occasionally observed at most study sites, with the highest frequency recorded at San Luis, followed by Cosumnes. Table 3 summarizes frequencies and percentages of superseded sticks for each site where it occurred. In the case of San Luis and Cosumnes, most supersedures were between $M$. apicalis and wasps. There were, however, rare supersedures at all sites that involved bees and other invertebrates such as earwigs and ants. The small percentages of supersedures indicate that little infor- mation was lost by eliminating these nests from analysis of frequency data.

Separate Bee Analysis for Specific Sites. Differences were observed between yearly counts for certain bee species at the same site (Figs. 2-4). Interest as to which bee species varied the most between years at the same site lead to a simulation test that was carried out for each bee species at each site where there was sufficient data. Results of the analysis are presented in Table 4. Most of the bee species examined showed statistically significant differences in frequency from year to year at the $P=0.01$ level. Although 4 species 
Table 2. Poisson regression on the Splus GLM program

\begin{tabular}{lccc}
\hline $\begin{array}{c}\text { Terms added } \\
\text { to model }\end{array}$ & $\begin{array}{c}\text { Changes in } \\
\text { degrees of } \\
\text { freedom }(\mathrm{df})\end{array}$ & $\begin{array}{c}\text { Remaining } \\
\mathrm{df}\end{array}$ & $\begin{array}{c}\text { Change in } \\
\text { deviance }\end{array}$ \\
\hline Intercept only & & 83 & \\
Bee & 6 & 77 & 2,646 \\
Site & 3 & 74 & 2,494 \\
Year & 2 & 72 & 14.40 \\
Year $\times$ bee & 12 & 60 & 123.1 \\
Site $\times$ bee & 18 & 42 & $1, \tilde{5} 49$ \\
Site $\times$ year & 6 & 36 & 53.88 \\
\hline
\end{tabular}

Factors in the model are bee: MAP, OLG, OTX, MAN, MFD, MRT and TRY (wasp) (see Table 1 for names of taxa). Site: CO, Cosumnes SL, San Luis; CR, Creighton Ranch; SJ, San Joaquin; and years 1990 1991, and 1992.

${ }^{a}$ All changes in deviance were significant at the $P=0.01$ level with respect to chi-square distribution.

experienced no statistically significant change in frequency at Cosumnes and San Luis, 3 of the same 4 bee species (Megachile rotundata, Osmia texana and Megachile angelarum) did experience statistically significant changes at other sites. The 4th species (Megachile fidelis) was the only bee whose nesting frequency did not change at the 2 sites where it was encountered in sufficient numbers.

\section{Discussion}

Overall results of the 1 st and 2 nd study phases (1987-1989; 1990-1992, respectively) indicate that there were significant differences in the communities of cavity-nesting bees among the 6 study sites. Differences were revealed through Poisson regression analysis and through examination of obvious species differences in Figs. 2-4 (and in Table 1 of Thorp et al [1992]). A different trap-nesting fauna was recorded at the coastal mountain/Sierran foothill sites than at the San Joaquin valley sites; also, introduced bee species were present in trap nests in the Valley, but not in the mountains.

In the case of 2 valley sites, frequency and diversity of cavity-nesting bees may be related, in part, to amount and type of riparian habitat. Riparian plants at Cosumnes were more diverse in both the overstory and understory layers than San Luis. Further, the
Table 4. Differences in frequencies of bees and wasps between years for selected species at same site (see Figs. 2-4)

\begin{tabular}{lllll}
\hline \hline $\begin{array}{c}\text { Statistical } \\
\text { significance }\end{array}$ & Cosumnes & San Luis & $\begin{array}{c}\text { Creighton } \\
\text { Ranch }\end{array}$ & San Joaquin \\
\hline Significant & Meg. api. & Meg. api & Meg. rot. & Osm. lig. \\
& Meg. ang. & Meg. rot. & Trypox. & Trypox. \\
& Osm. tex. & Trypox. & & \\
Not significant $^{a}{ }^{a}$ Meg. rot. & Osm. tex. & & \\
& Meg. fid. & Meg. ang. & & \\
& Trypox. & Meg. fid. & & \\
\hline
\end{tabular}

See Table 1 for full names of taxa.

${ }^{a}$ At $P=0.01$ level.

forest along riparian corridors at Cosumnes is older, wider, and in some places developed into small groves of trees. Valley oak, Q. lobata, is a predominant species in these corridors. In contrast, the riparian forest at San Luis is generally younger and fragmented in numerous places, especially along the San Joaquin river, where many of our trap nest blocks were located. Two species of willow, Salix species, predominated in the riparian forest of San Luis. These habitat differences probably account for some of the differences in bee diversity and abundance recorded between these 2 sites. The situation at San Luis could change in the future, however, with the extensive riparian reforestation program that has been ongoing there since 1992. Overall however, the large scale destruction years ago of riparian corridors by $>95 \%$ throughout the Central Valley of California (Warner and Hendrix 1984, 1985; Faber and Holland 1988) greatly reduced one of the most important habitats for cavity-nesting bees-for the species recorded in this study and probably numerous others (compare bee species in valley sites in table 1 of Thorp et al. 1992). What remains of the corridors is at best sparse and fragmentary in most locations.

All but 1 of the selected bee species monitored in this study changed in frequency through time (Tables 3 and 4$)$. The changes differed for different species and at different sites; there did not seem to be any pattern followed by all species at a site or between sites, for example from some major climate change. Change in frequency was particularly dramatic at Creighton Range where several Megachile species

Table 3. Frequencies and percentages of total and bee only supersedures at each site by year

\begin{tabular}{|c|c|c|c|c|c|c|c|}
\hline \multirow[t]{3}{*}{ SL } & 1990 & 48 & 597 & 8.0 & 44 & 546 & 8.1 \\
\hline & 1991 & 55 & 582 & 9.4 & $\tilde{5} 4$ & 550 & 9.8 \\
\hline & 1992 & 28 & 520 & 5.4 & 28 & 500 & 5.6 \\
\hline $\mathrm{CO}$ & 1990 & 23 & 342 & 6.7 & 23 & 270 & 8.5 \\
\hline \multirow[t]{2}{*}{ SJ } & 1990 & 1 & 76 & 1.3 & 1 & 64 & 1.6 \\
\hline & 1992 & 4 & 103 & 3.8 & 4 & 87 & 4.6 \\
\hline $\mathrm{CR}$ & 1991 & 2 & 75 & 2.7 & 2 & 27 & 7.4 \\
\hline $\mathrm{HR}$ & 1992 & 1 & 196 & 0.5 & I & 127 & 0.8 \\
\hline
\end{tabular}

SL, San Luis; CO, Cosumnes; SJ, San Joaquin; CR, Creighton Ranch; HR, Hastings Reserve. 
dropped out altogether or declined to undetectable levels (Fig. 2). Fluctuations in annual frequencies appears to be a regular characteristic of cavity-nesting bee species. Other trap nest studies, having 2 or more years of data, have also revealed changes in bee frequencies through time (Frankie et al. 1993, Strickler et al. 1996).

Our trap nest monitoring study has continued uninterrupted from 1987 to the present and is beginning to offer insights on some of the factors that could singly or in combination influence bee frequency changes; these include the following 4 points: (1) Differential natural mortality. This mortality can occur during early larval development when a variety of parasitic and predatory invertebrates are active or during the overwintering period when bacterial and fungal pathogens are most active. We are currently surveying mortality factors at Cosumnes, San Luis and Creighton Ranch. (2) Extreme annual weather patterns. Drought or above normal rainfall years could be a major factor in influencing floral resources and bee frequencies. Our long-term data collections and analysis through drought periods (1987-1993) and through normal/above normal rainfall periods (19941998) should provide important information on the general effects of weather changes on habitat resources and bee populations. (3) Marginal habitats. Habitats that have been disturbed, fragmented or isolated (Vinson et al. 1993; Frankie et al. 1993, 1998; Matheson et al. 1996) could result in major changes in annual bee frequency, especially if other factors such as natural mortality and extreme climatic changes exacerbate existence in marginal habitats. (4) Negative impact from exotic bees. Competition from exotic bee species for floral food and/or nesting sites could greatly affect the frequency of native bees (Thorp et al. 1992, Barthell and Thorp 1995, Matheson et al. 1996, Barthell et al. 1998).

Regarding negative impacts from exotic bees (point 4), 3 exotic species were observed using trap nest blocks: M. apicalis, M. rotundata, and M. concinna. The most common of these was $M$. apicalis. The extent to which this species can increase in numbers was best observed at San Luis where the annual frequency was always higher than at any other site (Fig. 3). By midsummer at San Luis it seemed that every available cavity in the environment was being searched by females for possible use as a nest; high competitiveness for nest cavities is a behavioral trait in this species (Barthell and Thorp 1995, Thorp 1996). There are other features that also make this species competitive against native leaf-cutter bees. Nest morphology and methods of assembling leaf discs in the subgenus $\mathrm{Eu}$ tricharaea, to which $M$. apicalis belongs, differ from those of native Megachile, particularly the subgenus Litomegachile (Kim 1992). Nest morphology in Eutricharaea is characterized by leaf discs glued together, thus allowing females to nest in cavities with a variety of internal shapes and secondarily protecting brood from certain nest parasites such as Mellitobia. Conversely, leaf discs are not glued together in nests of Litomegachile, which requires more uniform cylindri- cal nest cavities and is more vulnerable to parasitism. In addition, $M$. apicalis is a multivoltine species with high female reproductivity (W. P. Stephen, Oregon State University, unpublished data; P. F. Torchio, USDA, Utah State University, unpublished data). Spring generation females may construct 3 cells a day, and this is partly attributed to the abundance of host flowering plant species, especially yellow star thistle, Centaurea solstitialis L. (Kim 1996).

The potential of M. apicalis as a nest competitor with other bee species has also been observed by Stephen and Fichter (1989). It seems that it may compete with $M$. rotundata for nesting holes where populations of the 2 species overlap (see also Trostle and Torchio 1994). M. rotundata became established in California in the early 1950s (Hurd 1954); with M. apicalis in the state by 1982 (Cooper 1984, Thorp et al. 1992). M. rotundata usually begins nesting earlier in the season and apparently peaks before M. apicalis (Stephen and Torchio 1961; Thorp et al. 1992). Once nesting frequency of $M$. apicalis increases substantially during the season, however, $M$. rotundata becomes scarce. It is possible that overall lower frequency of nesting $M$. rotundata in our study is due to the high frequency of M. apicalis, which may be out competing $M$. rotundata for nest sites and perhaps other species as well.

Based on monitoring results from 1990 to present, it seems clear that the use of trap-nest frquency data alone will not provide for an appropriate assessment of possible negative impacts of Africanized honey bees on solitary bees, which is the overall goal of this research program. Other relevant data being developed in this program concerns floral resource overlap between European honey bees and solitary bees, which may ultimately provide a better assessment of impacts.

To conclude, results of this research to date provide a glimpse of the extant, highly variable communities of cavity-nesting bees at 6 sites in northern California. It is obvious that human activities, in the form of habitat development/disturbance have played a major role in modifying the environments of native bees at each site. These modified environments pose challenging obstacles, questions, and opportunities for understanding how native bees adjust to dynamic changes through time.

\section{Acknowledgments}

We thank the following individuals who assisted with logistics at the study sites, which greatly facilitated our work: Mark Stromberg (University of California), Craig Streeper (Nature Conservancy), and Dennis Woolington (USFWS). P. F. Torchio (USDA, Utah State University) and W. P. Stephen (Oregon State University) kindly read an early draft of the manuscript. We thank the following organizations for their logistic support and cooperation during the course of the study: The Nature Conservancy (Cosumnes Reserve and Creighton Ranch); U.S. Fish and Wildlife Service (San Luis Wildlife Refuge); California Department of State Parks (Mt. Diablo); University of California Natural Reserve System (Hastings Reserve); U.S. Forest Service and Fresno State University (San Joaquin Experiment Range). The research 
was supported through a regional project (W-180) of the California Agricultural Experiment Station.

\section{References Cited}

Arretz, P. 1969. Effect of temperature on the development and mortality of immature stages of Megachile rotundata Fabr. M.S. thesis, University. of California, Davis.

Arretz, P. 1973. Factores de mortalidad de Megachile rotundata (Fabricius) en Chile (Hymenoptera: Megachilidae). Rev. Chile Entomol. 7: 59-78.

Barthell, J. F., and R. W. Thorp. 1995. Nest usurpation among females of an introduced leaf-cutter bee, Megachile apicalis. Southwest. Entomol. 20: 117-124.

Barthell, J. F., G. W. Frankie, and R. W. Thorp. 1998. Invader effects in a community of cavity- nesting megachilid bees. Environ. Entomol. 27: 240-247.

Beyer, W. N., G. W. Miller, and W. J. Fleming. 1987. Populations of trap-nesting wasps near a major source of fluoride emissions in western Tennessee USA. Proc. Entomol. Soc. Wash. 89: 478-482.

Cooper, K. W. 1984. Discovery of first resident population of the European bee, Megachile apicalis, in the United States (Hymenoptera: Megachilidae). Entomol. News 95: 225-226.

Faber, P. M., and R. F. Holland. 1988. Common riparian plants of California. Pickleweed Press, Mill Valley, CA.

Frankie, G. W., S. B. Vinson, L. E. Newstrom, and J. F. Barthell. 1988. Nest site and habitat preferences of Centris bees in the Costa Rican dry forest. Biotropica 20: 301-310.

Frankie, G. W., L. Newstrom, S. B. Vinson, and J. F. Barthell. 1993. Nesting-habitat preferences of selected Centris bee species in Costa Rican dry forest. Biotropica 25: 322-333.

Frankie, G. W., S. B.Vinson, M. A. Rizzardi, T. L. Griswold, S. O'Keefe, and R. R. Snelling. 1998. Diversity and abundance of bees visiting a mass flowering tree in disturbed seasonal dry forest, Costa Rica. J. Kans. Entomol. Soc. 70: 281-296.

Frohlich, D. R., and F. D. Parker. 1985. Observations on the nest-building and reproductive behavior of a resin-gathering bee: Dianthidium ulkei, Hymenoptera: Megachilidae. Ann. Entomol. Soc. Am. 78: 804-810.

Gathmann, A., H. J. Greiler, and T. Tscharntke. 1994. Trapnesting bees and wasps colonizing set-aside fields: succession and body size, management by cutting and sowing. Oecologia (Berl.) 98: 8-14.

Hurd, P. D., Jr. 1954. Distributional notes on Eutricharaea, a palearctic subgenus of Megachile, which has become established in the United States. Entomol. News 65: 93-95.

Jacob-Remacle, A. 1986. Motalité de quelques Hyménoptères Aculéates nidifiant dans des nichoirs-pièges. Bull. Ann. Soc. Belge Entomol. 122: 107-118.

Jayasingh, D. B., and B. E. Freeman. 1980. (1981). Trapnesting solitary aculeates, Insecta: Hymenoptera, in St. Catherine, Jamaica. Caribb. J. Sci. 15: 69-78.

Kim, J.-Y. 1992. Nest dimensions of two leaf-cutter bees (Hymenoptera: Megachilidae). Ann. Entomol. Soc. Am. 85: 85-90.

Kim, J-Y. 1996. Maternal investment and reproductive strategies of an adventive leaf-cutter bee, Megachile apicalis (Hymenoptera: Megachilidae). Ph.D. dissertation, University of California, Davis.

Krombein, K. V. 1967. Trap-nesting wasps and bees: life histories, nests and associates. Smithsonian Institution Press, Washington, DC.
Matheson, A., S. L. Buchmann, C. O’Toole, P. Westrich, and I. H. Williams [eds.]. 1996. "The Conservation of Bees." Academic, London.

McCullagh, P., and J. A. Nelder. 1989. Generalized linear models, 2nd ed. Chapman \& Hall, New York.

Medler, J. T., and T. W. Koerber. 1958. Biology of Megachile relativa Cresson (Hymenoptera, Megachilidae) in trapnests in Wisconsin. Ann. Entomol. Soc. Am. 51: 337-344.

Parker, F. D. 1986. Factors influencing mortality and nesting in managed populations of the sunflower leafcutter bee Eumegachile pugnata, Hymenoptera: Megachilidae. Environ. Entomol. 15: 877-879.

Parker, F. D. 1987. Nest of Callanthidium from block traps (Hymenoptera: Megachilidae). Pan-Pac. Entomol. 63: 125-129.

Parker, F. D., and R. M. Bohart. 1966. Host-parasite associations in some twig-nesting Hymenoptera from Western North America. Pan-Pac. Entomol 42: 91-98.

Parker, F. D., and R. M. Bohart. 1968. Host-parasite associations in some twig-nesting Hymenoptera from western North America. Part II. Pan-Pac. Entomol 44: 1-6.

Payne, C. D. 1986. The generalized linear interactive modelling system. Release 3.77. The GLIM System Manual, Royal Statistical Society, Oxford.

Raw, A. 1992. Solitary bees (Hymenoptera: Megachilidae), restricted to identical resources for nesting, recognized their own nests: An example of genetically determined personal scents? The Entomol. 111: 79-87.

Stephen, W. P., and B. L. Fichter. 1989. Mortality factors in developing leafcutting bees. Annual Report, Oregon State University, Corvallis.

Stephen, W. P., and P. F. Torchio. 1961. Biological notes on the leafcutter bee Megachile (Eutricharaea) rotundata (Fabricius) (Hymenoptera: Megachilidae). Pan-Pac. Entomol. 37: 89-93.

Strickler, K., V. L. Scott, and R. L. Fischer. 1996. Comparative nesting ecology of two sympatric leafcutting bees that differ in body size (Hymenoptera: Megachilidae). J. Kans. Entomol. Soc. 69: 26-44.

Tepedino, V. J., J. M. Loar, and N. L. Stanton. 1979. Experimental trapnesting: Notes on nest recognition in three species of megachilid bees (Hymenoptera: Megachilidae). Pan-Pac. Entomol. 55: 195-198.

Thorp, R. W., G. W. Frankie, J. F. Barthell, D. Gordon, L. E. Newstrom, T. L. Griswold, J. O. Schmidt, and S. Thoenes. 1992. Ecological research ... long term studies to gauge effects of invading bees. Calif. Agric. 46: 20-33.

Thorp, R. W. 1996. Resource overlap among native and introduced bees in California, pp. 143-151. In A. Matheson, S. L. Buchmann, C. O'Toole, P. Westrich, and I. H. Williams [eds.] The Conservation of Bees. Academic, London.

Torchio, P. F. 1984. Discovery of Osmia tanneri, Hymenoptera: Megachilidae, nesting in drilled wood trap nests. J. Kans. Entomol. Soc. 57: 350-352.

Trostle, G., and P. F. Torchio. 1994. Comparative nesting behavior and immature development of Megachile rotundata (Fabricus) and Megachile apicalis Spinola (Hymenoptera: Megachilidae). J. Kans. Entomol. Soc. 67: 53-72.

Undurraga, J. M., and W. P. Stephen. 1980. Effect of temperature on development and survival in post-diapausing alfalfa leafcutting bee prepupae and pupae (Megachile rotundata (F): Hymenoptera: Megachilidae). I. High temperatures. J. Kans. Entomol. Soc. 53: 669-676.

Vinson, S. B., G. W. Frankie, and J. Barthell. 1993. Threats to the diversity of solitary bees in a neotropical dry forest 
in Central America, pp. 53-81. In J. LaSalle and I. D. Gauld [eds.], Hymenoptera and biodiversity. CAB, Wallingford, UK

Warner, R. E., and K. M. Hendrix. 1984. California riparian systems, ecology, conservation, and productive management. University of California Press, Berkeley, CA.
Warner, R. E., and K. M. Hendrix. 1985. Riparian resources of the Central Valley and California Desert. California Department of Fish and Game, Sacramento, CA.

Received for publication 16 October 1997; accepted 11 June 1998. 